\title{
Stop! Push-Parenting: Shoot Parent's Ambition as Kind of Psychological Abuse in Parenting
}

\author{
Laily H idayati \\ Received: 24102016 / Accepted: 1312 2016 / Published online: 13122016 \\ ๑ 2016 Association of Indonesian Islamic Kindergarten Teachers Education Study Program
}

\begin{abstract}
Abstrak M enyiapkan masa depan terbaik untuk anak adalah hal yang sangat wajar dilakukan oleh orangtua manapun. Memastikan kebutuhan dasar anak terpenuhi, memastikan pendidikannya, fasilitas-fasilitas, bahkan dana, merupakan hal-hal umum yang dilakukan oleh orangtua dalam rangka itu. Pada prosesnya, tidak bisa tidak, orangtua menerapkan cara-cara yang secara tipikal mereka gunakan-meskipun seringkali tidak disadari-dalam mengasuh dan mendidik anak mereka. Cara-cara yang secara khas digunakan oleh orangtua dalam mengasuh dan mendidik anaknya disebut dengan pola asuh (parenting), yang mana telah dikenal terdapat beberapa pola asuh yang lazim diterapkan oleh orangtua.Push-parenting adalah istilah yang digunakan untuk menyebut suatu pola asuh yang terlalu menekan hak anak, cenderung menetapkan target-target, tuntutan-tuntutan, standar-standar yang sangat mungkin melewati batas kemampuan fisik maupun psikologis anak. Yang terjadi kemudian adalah terancamnya kesehatan mental anak karena anak berubah menjadi miniatur serta korban pemaksaan ambisi orangtua. Anak dapat menjadi rendah diri, konsep dirinya negatif, terganggu aspek perkembangan sosial-emosionalnya, dan lebih-lebih, anak kehilangan kesempatan untuk berkembang jiwa kemandirian serta kemampuannya menyelesaikan masalah (problem solving). Artikel ini mendalami kajian-kajian teoritis kepustakaan, menganalisisnya untuk menemukan titik kritis penerapan model pengasuhan push-parenting, sehingga dengannya, orangtua diharapkan dapat mengevaluasi pola asuh yang diterapkannya,sehingga anak dapat tumbuh-berkembang secara unik sesuai bakat, minat, serta kepribadiannya.
\end{abstract}

Kata Kunci: Parenting, push-parenting, kekerasan psikologis.

\begin{abstract}
Preparing for the best children's future is a very reasonable thing to do by any parent. Ensure the basic needs of children are met, ensure their education, facilities, and even funding, are the general things are done by parents in order that. In the process, we all know and sure that parents implement ways that typically they use-although often they do not realized_in caring for and educating their children. Ways that are typically used by parents in caring for and educating children is called parenting (parenting), which has been known there are some common parenting applied by parents. Push-parenting is a term used to describe a parenting that in there too much pressure on children's rights, tend to set targets, demands, standards that are likely over the limit of physical and psychological abilities of children. What happens then is the threat to children's mental health because children turn into a miniature as well as victims of coercion parental ambition. Children can going to be a low self-esteem, negative self-concept, disturbed aspects of social-emotional development, and more, children maybe lose the opportunity to develop spirit of independence and ability to solve problems (problem solving). This paper scrutinizes the
\end{abstract}


theoretical literature studies, analyzes it to find a critical point of care model application pushparenting, so with that, parents are expected to evaluate the implementation of parenting, so that the child can grow-evolved uniquely suited their talents, interests, and personality.

Keywords: Parenting, push-parenting, psychological abuse.

\section{Introduction}

Family is the first social group where children interact. Family has significant influence to the formation and development of personality. $M$ any factors in a family affects to the process of child development. One of the factors in a family that has important role in the formation of personality is a child care or nurturing practices. This is corroborated by the opinion of Brown (1961) which says that the family is the first environment that accepts the presence of children. Parents have a variety of functions that one of them is to care for their child. In caring for children, parents affected by the culture in the environment. In addition, parents are also colored by certain attitudes within nurture, guide, and direct their children. The attitude reflected in the pattern of different care to their children, because parents have certain parenting styles.

Parenting according to Stewart and Koch (1983) consists of three tendencies of parenting style: authoritarian, democratic and permissive parenting. As a caregiver and educator in the family, parents have a very significant role in laying the groundwork for their children's behavior. Attitudes, behaviors, and habits of the parents has always been seen, assessed, and imitated by children then it_consciously or unconsciously_internalized by the children and then become habits anyway. This because as children identify themselves on their parents before holding identification with others. M elly Budiman (1986) says that the families that full with compassion is very important for children so that children develop good social behavior. When the compassion is not there, then it is often the children will find difficulties in building social relationships, and these difficulties will lead to a wide range of behavioral disorders as an effort to compensation for them.

Then the family becomes the first circumference ring in the life ring of children. The ring that will assure the accomplishment of purpose of nurturing and education. If the atmosphere in the small circle of the ring was cool and full with love, then the children who grow up in it would be a child who unearthed all the potential talents and interests, maintained their socialemotional development, physical and psychological healthy. With the goal of peeling and find the facts behind the models of parenting, this paper was written within the framework of the study of children developmental psychology in the family.

\section{Definition of Parenting}

According to the Indonesian big dictionary (2002), the notion of parenting is a form (structure), the system in maintaining, caring for, educating and guiding children. While the pattern of parenting by Soetjiningsih (2004) is a model or a way to educate children is an obligation of every parent in forming a children's personalities to the expectations of society at large. In the 
report of Scientific Meeting of the National Child Welfare System, 1998 (in Garliah, 2003) parenting is defined as a set of attitudes and behaviors are arranged, which are applied by parents to interact with their children. Kohn, 1986 (in Tarmudji, 1991) says that parenting is the attitude of parents to interact with their children. Parent attitudes include how parents give the rules, prizes and punishments, the way parents show his authority, and how parents give attention and response to his children. The family size has an influence on family upbringing and the results achieved by children. Large families and small families qualitatively describe the experiences of development. Children who come from small families receive more attention than children from large families. Research has linked this difference with intellectual development and performance in school performance (Feiring and Lewia, 1984).

A ccording to Jack and Judith Balswick (1989), based on socio-emotional approach known four styles of parenting, (1) neglectful parenting, parenting style that is weak in the support and supervision; (2) permissive parenting, parenting style that is weak but strong supervision in support; (3) Authoritarian parenting, parenting style in support of the weak, but strong in supervision; (4) authoritative parenting, parenting style that combines the best qualities of the permissive and authoritarian style.

Cynthia Crosson-Tower (2003) in her research entitled "The Role of Educators in Preventing and Responding to Child Abuse and Neglect" on the role of educators in the prevention and treatment of abuse and neglect of children describing the three pillars of child protection, namely: safety, permanency, and child and family well-being. Safety refers to the sense of security that must certainly exist in the child's life. Provision warm environment and free from abuse and neglect. Permanency refers to permanent residence who can be called the residence. Children need continuity and flavors blend together so that it becomes a place of residence for growing relatively stable. Child and family well-being refers to the existence of a family environment to ensure the health of the physical, psychological, emotional, educational, and social.

Lidanial in the Veritas journal (2006) revealed the bad effects of push-parenting in child care. Push-parenting emphasizes the child should get the best education, and showed the best performance anyway. Idealism and ambition of parents to create a perfect child and the child's upper class apparently also opens up opportunities to inhibit the development of the children themselves. Excessive demands are given by parents to their children, which he said aimed at "only" for the sake of the future of the children themselves, the truth needs to be questioned again. "Only" for the sake of the child or there is some parents "mission" shrouded in it.

There is no parents want their children depressed and did not enjoy their childhood, but unconsciously with push-parenting, a lot of parents has claimed the happiness of childhood of their children. In the push-parenting, parents will only support the wishes of children in accordance with their ambitions, and they will do an extra tight supervision during the process of achieving that ambition. What are the interests of children are often overlooked by parents. It should be recognized children are still in desperate need of guidance and monitoring of their 
parents. But in the push-parenting seems children are not given the opportunity to express themselves, including any of their competence, which may not be realized by the parent.

Ellen Skinner, Sandy Johnson, and Tatiana Snyder (2005) in a study entitled "Six Dimensions of Parenting: A M otivational M odel" suggests six dimensions of child care that can be used as a reference in the practical care of children by parents. Dimensions offered parenting refers to the shape or pattern, quality, descriptive scheme that is used as a reference for this concept of it was built on a variety of parenting applicable. The six dimensions of parenting include: warmth, rejection, structure, chaos, autonomy support, and coercion.

Push-parenting in this study is similar to what was presented by Ellen Skinner, Sandy Johnson, and Tatiana Snyder as "coercion", that is parenting completely overbearing parents toward anything related to the rights and obligations of the child, combined with the pattern of "structure", that is full parenting rules set by parents to their children. The questionnaire was developed by Ellen Skinner, Sandy Johnson, and Tatiana Snyder explicitly explain how the treatment of a parent or methods used by parents in implementing parenting on their children. Here are some items indicators of coercion parenting in the questionnaire dimensions of parenting.

Table 1.

Some items indicators of coercion parenting in the questionnaire dimensions of parenting

\begin{tabular}{|c|c|}
\hline PARENTSREPORT & CHILDREN REPORT \\
\hline \multicolumn{2}{|c|}{ COERCION } \\
\hline M y child fights me at every turn & My parents are al ways telling me what to do \\
\hline $\begin{array}{l}\text { To get my child to do something, I have to yell at } \\
\mathrm{him} / \mathrm{her}\end{array}$ & My parents boss me. \\
\hline $\begin{array}{l}\text { I can't afford to let my child decide too many } \\
\text { things on his or her own }\end{array}$ & $\begin{array}{l}\text { M y parents think there is only one right way to do } \\
\text { things-their way }\end{array}$ \\
\hline $\begin{array}{l}\text { I sometimes feel that I have to push my child to } \\
\text { do things. }\end{array}$ & My parents say "no" to everything \\
\hline $\begin{array}{l}\text { I find myself getting into power struggles with my } \\
\text { child. }\end{array}$ & $\begin{array}{l}\text { The only reason my parents give is "Because I said } \\
\text { so." }\end{array}$ \\
\hline & I'm not allowed to disagree with my parents. \\
\hline & M y parents try to control everything I do. \\
\hline & $\begin{array}{l}\text { My parents think that they know best about } \\
\text { everything. }\end{array}$ \\
\hline \multicolumn{2}{|c|}{ STRUCTURE } \\
\hline $\begin{array}{l}\text { I make it clear what will happen if my child does } \\
\text { not follow our rules. }\end{array}$ & $\begin{array}{l}\text { When I want to do something, my parents show } \\
\text { me how }\end{array}$ \\
\hline $\begin{array}{l}\text { I make it clear to my child what I expect from } \\
\mathrm{him} / \mathrm{her} \text {. }\end{array}$ & $\begin{array}{l}\text { When I want to understand how something } \\
\text { works, my parents explain it to me. }\end{array}$ \\
\hline When I punish my child, I always explain why. & $\begin{array}{l}\text { If I ever have a problem, my parents help me to } \\
\text { figure out what to do about it. }\end{array}$ \\
\hline When I tell my child I'll do something, I do it & $\begin{array}{l}\text { My parents explain the reasons for our family } \\
\text { rules. }\end{array}$ \\
\hline If my child has a problem, I help him/her figure & My parents expect me to follow our family rules. \\
\hline
\end{tabular}


out what to do about it.

I expect my child to follow our family rules. My parents show me how to do things for myself My parents keep their promises.

When my parents tell me they'll do something, I

know they will do it.

Elisabeth Guthrie and Kathy Matthews in Qanita (2003), describes some behavioral characteristics that some sign of the push-parenting, as follows:

1. Set up almost every minute of her life with the courses, social ization programs and activities "enrichment" others.

2. Demand high achievement in school and in various other fields, almost by all means (emotional, psychological, physical, and financial).

3. Pressing the children choose courses, training, or more interest for the purpose of making CV (Curriculum Vitae) or an impressive resume than to satisfy a natural curiosity and personal interest.

4. Interfere friendships and relationships of children with the teacher and coach.

Parents who apply push-parenting assumes that children will not succeed in their future life, if parents do not "help" them completely. Children are not at all able to decide their own responsible choices for their future. Because of that, parents think that they have to choose everything for them and they should follow it, even with a forced condition.

Violence against children is not limited to physical violence, but also psychological violence, for example, impose the will, does not provide appropriate facilities talents and interests of children, not give the children a space to discuss so they can express their personal opinion, and others. Bagong Suyanto (2010) revealed that psychological violence is a violence that does not give an obvious former to the victims, so the perpetrators of violence are sometimes not aware that he apparently has done a psychological violence. Concrete manifestation of this form of violence is; the use of harsh words, abuse of trust, humiliate someone in public, made threats with words and so on.

\section{Push-Parenting as a Model of Parenting}

In this discussion the author would like to emphasize the most crucial negative effects of pushparenting model, which is likely to be lost or never establishment of independence in children, also when the children have a poor experience in learning or training to a decision making. A uthors assess these two things are most crucial for a child's education, an aspect that should be developed is not just the intellectual quotient (IQ), but also aspects of emotional quotient (EQ). In a completely depressed condition, the children will not or will be minimal chance to develop emotional abilities that definitely he will need when he grew up, among others, independence and skills to make decisions in real life when he has grown up.

According to the research of H enker (1983), everything that happens in the relationship between parent and children including emotions, reactions and attitudes of the parents will 
imprint and unconsciously embedded in someone life. What is embedded will be manifested later in a relationship with his own family. If the relationship with his parents once satisfying and happy, then the impression of positive emotions that will be embedded in the memory and brought to life when the child has grown up. In contrast, from the emotional experience less fun with their parents, will be recorded in the memory and cause stress. Meaning, there is the unfinished business of the past carried into the next life, including marriage. Any negative emotions from the past, carry over and affect emotions, perception / mindset and attitudes of those in the present.

Independence and decision-making skill are two basic skills that should begin to be imparted to children from an early age. Instill a positive self concept that "I can", will boost the confidence of children to independently complete the developmental tasks that passed by a child, and furthermore, will help the child to more easily make decisions and choices in life later when she grew up. In this model of parenting push-parenting where very thick feel authoritarian parents, would make poor children experience can forge his soul to be independent, because all their needs have been prepared and chosen for him by his parents. In that context, the pushparenting model of care becomes a form of psychological violence against children. Because in practice, parents impose his own ambition, not provide opportunities for children to acquire education and upbringing favoring personal uniqueness, claimed his freedom of expression and determining the talent-interest. Because, basically, as an adult, the child will live a life as himself, not the life his parents again.

Below are some examples of little things that appear in the application of push-parenting model of care as well as possible effects on personality and social-emotional condition of the child.

1. Choose schools based on parents' wishes and standards, not based on considerations agree or disagree with the character and needs of children. This can cause children to feel frustrated their daily lives in school so his performance is decreasing. It can also cover the possibility of actualization talent that may not be developed at the school.

2. Telling children to follow les-tutoring outside school hours, and choose the type of les to be followed by children. It can also cause children to feel frustrated and prone to stress because of the pressure and demands are excessive and incompatible with their personal interests. Furthermore, children with certain personality types would likely have turned against and showing resistance caused by too weighed the demands given by the parents. As described in the report of parents in parenting approach "corecion" in the literature review above. In contrast, children with a closed personality types will further demonstrate achievement of withdrawal and decline. And the sad thing is, these achievements are usually decline to make parents more pressing and demanding child, instead introspect their approach to motivate children's learning.

3. M ake a schedule of daily activities of children rigidly and without a child to advance the discussion. This addition can make children feel less confident in expressing his ideas, can 
also stifle the creativity of children. I deally, children should be given the opportunity to try as much as possible areas of interest so that it is rich learning experience. Thus parents can find out areas of interest which were full-loved by children, and consistent with the character personality.

4. Too many set restrictions on a subjective and irrational. For example forbids children to play with his close friend, prohibits children mix with other children in the neighborhood, and others. This can cause the child to easily stressed and frustrated and alienated from their surroundings.

5. Too many set rules rigidly without taking children to discuss first. For example the rules of eating, sleeping, playing, watching television, follow les-les, and others. Just like in the previous point, the child may feel depressed so there are two possibilities. The first one being moody and disturbed the stability of emotions, both being against and resist their parents.

6. To criticize almost any work or effort to learn the child, insults, comparing children with friends or relatives, and others. This can cause children to be low self-esteem, lack of confidence and impaired aspects of social-emotional development.

7. Providing too many sanctions or penalties aggravating child hoping the child was no repeat, without the balance of praise or appreciation when a child shows achievement or effort in learning. Same with the previous point, the child can feel negative self-concept, low selfesteem, lack of confidence and impaired aspects of social-emotional development.

8. U sing words that hurt when giving direction to the child. Impacts away, children may be less able to show respect to parents so that the advice and direction of a parent becomes difficult to be accepted by children.

9. Establish targets "success" to children at once the standard way that must be passed and carried out by children. For example reducing the hours of play, time spent watching television, hours traveled, hours snacks, and others. And replace it with adding hours of study, hours of tutoring, reading books, practicing, and others. As in the previous points, the child becomes less able to develop their creativity, vulnerable frustrated, disturbed social-emotional, and other negative effects.

\section{Conclusion}

Push-parenting even though at first glance appears to be a form of high attention given by parents to children, to welcome and prepare their future. But if to be correct by the parents, the application of the model of parenting will impact negatively on the child's social-emotional condition. Unwittingly, parents have to impose the will and ambition and assume the child is a person without will, without the ability to choose, without the right to decide its own options. In such cases, children become susceptible to stress and frustration, deterioration of achievement and other adverse effects such as formation of negative self-concept, sense of inferiority or low self-esteem, decreased level of confidence, and others. 
Push-parenting in the process of education and nurturing of children, beside causes the problems of instability child's social-emotional, can also close the creation of a spirit of independence and skills children make decisions. Due to the application of the model of parenting nuanced authoritarian, coercion, and structure, as seen in the push-parenting, on the one hand a child has prepared a specific shape by parents, complete with a way to go, but on the other hand the children can be blunt their independence because they never get the time to practice decicion making, their talent and interests, and never get the time to practice problem solving by themselves.

Fortunately, children who grow up in a family who wisely sets the rules for children, wisely addressing the deficiencies of children, wisely directing and providing the option to actualize their talents and interest according to the character and personality. Because in the end, the children are the actors of their own life. Who will decide and go through all the possibilities_-that always be there certainly_and deal with the problems_that also always be there certainly_in their life when they grew up. Allah knows the best.

\section{References}

Baumrind, D. 1991. The influence of parenting style on adolescent competence and substance use. Journal of Early Adolescence.

Cynthia Crosson-Tower. 2003. The Role of Educators in Preventing and Responding to Child A buse and N eglect. U.S. Department of H ealth and Human Services.

Garliah, Lili. dkk. 2005. "Peran Pola Asuh Orang Tua Dalam Motivasi Berprestasi."Jurnal Psikologis.

Jack O. Balswick dan Judith K. Balswick. 1989. The Family: A Christian Perspective on the Contemporary Home. Grand Rapids.

Lidanial. 2006. Anak Korban Orang Tua A mbisius (Push Parenting) dan Konseling Terhadapnya. Bandung: Veritas.

M angoenprasodjo, A. Setiono. 2004. Pengasuhan anak di era internet. Jogjakarta: Thinfresh.

M artaniah, Sri M ulyani. 1964. Peranan orang tua dalam perkembangan Kepribadian.

Q anita. 2003. Anak Sempurna atau Anak Bahagia?: Dilema Orang Tua M odern. Bandung.

Skinner, Ellen dkk. 2005. Six Dimensions of Parenting: A M otivational M odel.

Soetjiningsih. 2004. Tumbuh Kembang Remaja dan Permasalahannya. Jakarta: PT. Rhineka Cipta.

Suyanto, Bagong (2010). M asalah Sosial A nak. Jakarta: Kencana. 